\title{
Anestrous in Buffaloes and Different Treatment Regimens: A Mini Review
}

\author{
Sandeep Kumar ${ }^{1}$, Gaurav Kumar ${ }^{2}$ and Subhash Chand Gahalot ${ }^{3}$ \\ ${ }^{1}$ CVH Hamirgarh, Animal Husbandry and Dairying Department, \\ District-Sangrur (Punjab), India 148027 \\ ${ }^{2}$ Department of Veterinary Surgery \& Radiology, Lala Lajpat Rai University of Veterinary \& \\ Animal Sciences, Hisar (Haryana) India 125004 \\ ${ }^{3}$ GVH Bichhore, Animal Husbandry and Dairying Department, \\ District- Nuh (Haryana), India 122508 \\ *Corresponding author
}

\section{A B S T R A C T}

\section{Keywords}

Anestrous,

Buffalo, Follicular dynamics, Ultrasonography

Article Info

Accepted:

10 February 2019

Available Online:

10 March 2019
Buffalo is regarded as Black gold and more than 50 per cent of the rural poor in India are dependent on livestock for their livelihood. The buffaloes have inherent problems of summer anestrous, poor expression of estrus and therefore prolonged calving to conception interval. The advent of ultrasonography has aided in better understanding of follicular wave pattern during cyclic and non-cyclic stages of reproductive cycle. The present review summarises various aspects of buffalo reproduction including Follicular dynamics, anestrous and different treatment regimens.

\section{Introduction}

India has vast resource of livestock, which plays a vital role in improving the socioeconomic condition of rural masses. India ranks $1^{\text {st }}$ in respect of buffalo, $2^{\text {nd }}$ in cattle and goat and $3^{\text {rd }}$ in sheep population in the world (Annual Report, Department of Animal Husbandry and Dairying, 2007-08). The country is highest milk producer of the world with annual milk production of 101.9 million tons (Anon, 2007). The milk is contributed mainly by buffaloes (55.5\%) followed by cattle $(40.0 \%)$ and goat $(4.5 \%)$, respectively. The proportionate contribution of livestock sector is Rs 984billion (5.51\%) of total Gross Domestic Product (DairyIndia, 2007).

The water buffalo domesticated since 5000 B.C. has attained important place in Indian economy. Considering the importance of buffaloes and its production potential, the 
buffalo has been termed as -The Black Gold (Acharya and Bhat, 1988). About 50 per cent of the rural poor in India are dependent on livestock for their livelihood (Thornton et al., 2002). The high yielding Murrah is the Holstein-Friesian of the buffalo world. Buffalo milk contains about twice as much butterfat as cow milk. Buffaloes are also valued for meat and draught purpose (Bandyopadhyay et al., 2003). In subtropical countries like India, the vagaries of climate like extreme hot humid environment with hot winds adversely affect the performance of buffaloes. The high ambient temperature during summer enhances level of prolactin which is anti-gonadotrophic (Kaker et al., 1981), thus affecting the hypothalamicpituitary-ovarian pathway resulting in acyclicity (Short et al., 1990). Basic reproductive physiology, with regard to regulation of ovarian functions pertaining to folliculogenesis, steroidogenesis and corpus luteum formation, structure, function and regression, has been studied more extensively in female cattle than inbuffaloes.

Understanding the mechanisms of folliculogenesis and follicular turnover during estrous cycle are essential for solving the problems of low reproductive efficiency in buffaloes. During late $1980^{\mathrm{s}}$, application of transrectal ultrasonography for imaging ovarian follicles opened up new vistas for studying folliculogenesis in cattle and buffaloes. Ovaries are theprimary organs of reproductive system, which undergo conspicuous structural changes during different stages of estrous cycle as a result of the growth and regression of follicles and corpus luteum (CL). Ultrasonography is relatively simple, effective and safe both to subject and operator, portable and ultra-rapid since the sonographic imaging facilitates immediate interpretation and diagnosis in most circumstances (Rajamahendran et al., 1994). Real time ultrasonic imaging provides a noninvasive and non-disruptive technique to directly examine external and internal anatomy of reproductive organs in situ and to monitor closely the dynamic reproductive events e.g. follicular, luteal growth and regression, pregnancy, transition of uterus from a diestrus to anestrus stage (Griffin and Ginther, 1992). Ultrasonography has facilitated immensely in better understanding of certain poorly understood areas ofthe reproduction (ovarian follicular dynamics, corpus luteal functions and pregnancy establishment). Infertility among dairy animals continues to be major bottle neck in exploiting the fullest production potential of our animal wealth. An annual loss due to reproductive inefficiency is more than 500 crore rupees (Dairy India, 2007). Reproductive efficiency isthe key determinant influencing productivity of the livestock and is adversely affected by late attainment of puberty, silent estrus, variability of estrous length, seasonality of calving, dystocia, genital prolapse, retention of fetal membranes, long postpartum anestrus and subsequent calving interval (Barile,2005). Low reproductive efficiency in the buffalo remains a major economic problem globally and its incidence is higher in India (Kumar et al., 2009). Prolonged postpartum acyclicity and anestrum are major causes of economic loss to buffalo breeders (El- Wishy, 2007). In India, incidence of anestrus in buffaloes has been reported from 25 to $67 \%$ (Singh et al., 2003; Pandit, 2004). Clinical survey revealed higher incidence of anestrus and inactive ovaries in buffaloes than in cows in India (Nagaraju et al., 1991). The percentage of anestrus is more in rural areas mainly due to malnutrition and improper managemental practices (Kumar and Sharma, 1991).

Attempts have been made by various researchers to induce cyclicity in anestrus buffaloes during peak breeding and low breeding periods with the help of hormonal 
and non-hormonal preparations (Lakra et al., 2002; Singh, 2003). Favorable effects of $\mathrm{GnRH}$ and its analogues in inducing early postpartum ovarian activity and estrus have been reported in buffaloes (Saini and Lohan, 2003). Progestogens have widely been used for induction of estrus and ovulation in acyclic animals. Hormonal preparations including PRID (Shah et al., 1987); Synchromate-B (Misra et al., 2003); Crestar, (Malik et al., 2003; Malik, 2005); Controlled Internal Drug Release followed by PMSG (Ravikumar et al., 2005; Singh, 2004) have been employed in the treatment of anestrus buffaloes. Duraprogen plus Progynon depot followed by PMSG have also been observed to provide encouraging results during breeding season and low breeding season (Singh, 2004). Recently, a novel protocol, Ovsynch '(GnRH-PGF $2 \alpha-G n R H$ regimen) was developed by Pursley et al. (1995) to synchronize ovulations in lactating dairy cows was also tried in buffaloes (De Rensis, et al., 2005; Malik, 2005) with variable degrees of success. The precise synchrony allows for successful fixed time A.I. without the need for detection of estrus and has been applied widely in cattle breeding. However, the comparative efficacy of these hormonal regimens of Ovsynch plus CIDR and Ovsynch plus progesterone in Murrah buffaloes during summer season has not been attempted.

Buffaloes hold immense socioeconomic importance to marginal farmers in several developing countries. The success of dairy cattle and buffalo husbandry lies in ensuring proper and optimal reproductive rhythm of each individual female in the herd. India has largest buffalo population (97 million) which account for 94.5-million-ton milk production (Dairy India 2007). Despite greater contribution in terms of milk production in relation to less population as compared to cattle, per head production of buffalo still remain low because of delayed puberty, higher age at first calving, longer inter calving interval, problem of heat detect ion, low conception rate, high stress of lactation and variation in conception during different months of year (Jainudeen et al., 2000). Anestrus in Indian buffalo due to smooth ovaries is the single largest cause of infertility (Parkinson, 2001). It is the most serious reproductive disorder of Indian buffaloes which affects farmer's economy by reducing calf crop and milk production. Out of various etiological factors like nutritional, lactational, stress etc. Malnutrition is the most common cause of anestrus under field condition. Sreemannarayana and Rao (1996) observed incidence of anestrus as high as $67 \%$ and $61 \%$ in rural cattle and buffaloes, respectively.

Postpartum anestrus in buffaloes is responsible for long calving intervals (Borghese et al., 1993) which is usually reported with higher frequency in primiparous and ageing buffaloes especially when the parturient period coincides with increasing daylight hours (Zicarelli, 1997), thereby, indicating a seasonal trend in reproduction (Campo et al., 2002). In addition to acyclicity, female buffaloes also experience weak estrus signs at irregular intervals with a propensity to develop ovarian pathology (Esposito et al., 1992). Estrus synchronization protocols, largely derived from cattle have yielded variable results in buffalo (Barile et al., 1997). Although failure of timed ovulation in synchronized buffaloes has been suggested as an important cause of poor fertility (Baruselli, 2001), it has not been studied critically. There are some research reports of ovarian follicular dynamics in buffalo (Manik et al., 1994; Taneja et al., 1996; Baruselli et al., 1997) but a critical comparison of the effects of age and parity on ovarian follicular dynamics and hormonal profiles has not been studied. A comprehension of the pattern of ovarian follicle recruitment and selection in 
postpartum buffaloes can provide required insight and lead to refinement of protocols for synchronization/induction of ovulation for successful artificial insemination. Conception rates after fixed time A.I. following estrus synchronization are considerably lower than those for A.I. at detected estrus, because of more variable interval to ovulation after $\mathrm{PGF}_{2} \square$ injection (Pursley et al., 1997a). Reduced fertility following these synchronization protocols made it necessary to understand ovarian follicular and $\mathrm{CL}$ dynamics in cattle. Synchronization of ovulation and fixed time artificial insemination (FTAI) is a promising protocol and has the potential to enhance pregnancy rates and success of A.I. programme. Ovsynch is one such estrus and ovulation synchronization protocol which has been used in lactating cattle for FTAI, stimulating ovarian follicle growth, maturation and ovulation (Pursley et al., 1995). Recently, success of Ovsynch was reportedly associated with pretreatment ovarian picture (Rohilla, 2003) and accordingly a modified protocol Ovsynch -Plus 'was tried in buffalo heifers (Singh et al., 2004). However, its application in postpartum buffaloes is yet to be assessed. Progestogens have al so been widely used for induction of estrus and ovulation in acyclic animals. Several researchers (Patel et al., 2003; Misra et al., 2003) used different progesterone preparations and got varied degrees of success. In buffaloes, Lohan et al., (2001) found that estrus induced with Crestar+PMSG were mostly anovulatory leading to poor fertility. In low breeding season, Crestar was not suitable for synchronization of estrus and ovulation (Bartolomeu et al., 2002).

The present review is an attempt to provide details of research carried out so faron various aspects of ovarian follicular dynamics during early postpartum period and anestrus condition as well as on estrus induction and synchronization particularly in buffaloes.

\section{Buffalo reproduction}

Despite several recent advances in the field of animal reproduction, infertility as manifested by true anestrus remains a major economic problem in the cattle and buffalo in most tropical countries. A long calving interval in the buffalo is mainly due to delay in resumption of ovarian cyclicity during early post-partum period.

\section{Puberty}

As compared to cattle, puberty is delayed in buffalo (Jainudeen and Hafez, 1993). The delay in puberty and consequent delay in conception is one of the main causes of low reproductive efficiency in buffalo, thus lengthening nonproductive life. Studies across the world indicate that puberty is significantly affected by breed, season, climate, feeding systems and growth rate (Borghese et al., 1994).

\section{Seasonality}

Although buffaloes are polyestrus, their reproductive efficiency shows wide variation throughout the year. Season of calving also influences onset of postpartum ovarian activity (Jainudeen et al., 1983), as buffaloes calving in summer resume ovarian activity earlier than those calving in winter (Lundstrom et al., 1982). Climate, and particularly photoperiod (by melatonin secretion), plays apivotal role in seasonality of estrus in buffaloes (Parmeggiani et al., 1993). The proportion of buffaloes exhibiting estrus during the period of short-day length is significantly greater than during the period of long day length, indicating that decreasing day light is a stronger determinant of the resumption of ovarian activity (Barile, 2005). Effect of heat stress has been observed on 
induced estrus also which was evident when same treatment in winter induced $100 \%$ cyclicity with $100 \%$ conception rate as compared to $72 \%$ cyclicity and $50 \%$ conception rate and more variable and silent estrus in summer (Markandeya et al.,1993).

\section{Estrus and estrous cycle}

Seasonal variation in duration of estrus has been reported in buffaloes with 14, 18 and 8 to $10 \mathrm{~h}$, respectively, during monsoon, winter and summer seasons (Janakiraman, 1978). The average duration of estrus in buffaloes has been reported to be 18 to $20 \mathrm{~h}$ with a range of 6 to $49 \mathrm{~h}$ (Gill et al., 1973). The interval from end of estrus to ovulation has been observed to be $11 \mathrm{~h}$ (range 5 to $24 \mathrm{~h}$ ) in Indian buffaloes (Luktuke and Ahuja, 1961). Buffaloes exhibited bellowing, frequent urination, restlessness, swollen vulva and mucus discharge as important estrus symptoms (Singh et al., 1984). Silent estrus (ovulation unaccompanied by estrus) is a major problem in buffalo breeding (Jainudeen, 1984). Use of vasectomized teaser bull has solved the problem of estrus detection to some extent, but it is laborious and time-consuming process.

\section{Ultrasonographic monitoring}

Transrectal ultrasonic imaging provided a means for repeated, direct, non - invasive monitoring and measuring of follicles regardless of their depth within the ovary (Johnson et al., 1994; Garcia et al., 1999). The technique has been used to diagnose pregnancy, fetal number and viability in small ruminants for the last several years (Buckrell, 1988).

Ultrasonography utilizes high frequency sound waves to produce images of tissues and internal organs. The sound waves are produced by vibrations of specialized crystals called - piezoelectric crystal housed in the ultrasound transducer. Pulse of electric current produces the vibrations of these crystals and high frequency sound waves are generated. By positioning of transducer, the sound waves are directed at the target tissue for reflection which are called echoes. These echoes are inaudible to human ear. The proportion of sound waves that is reflected or echoedis received by the same - piezoelectric crystals converted into electrical impulses and displayed on the ultrasound screen/monitor as a series of grey dots extending from black to white. These sound waves produce echoes that vary in intensity depending on the density of reflecting surface. Liquid do not reflect sound wave, therefore, the image of a liquid containing structure is non -echogenic and appears black on the screen, e.g. ovarian follicular fluid, cystic fluid, embryonic vesicle etc. Dense tissue strongly reflects sound waves and appears white on the screen and being termed as hyper-echogenic structures e.g. fetal bones, pelvic bones, cervix etc. Soft tissues reflect sound waves and produce image of varying grey shades and called echogenic e.g. corpus luteum, endometrium etc.

Ultrasonography has proved to be an effective means of monitoring and evaluating ovarian follicles in bovines (Pierson and Ginther, 1988). In heifers, ultrasonographic monitoring of individual follicles has been used to study the temporal association between FSH surges and initiation of follicular wave (Adams et al., 1992). Taneja et al., (1996) monitored effect of the presence of dominant follicle (DF) and concluded that superovulatory response can be improved by ultrasonographic observation of status of follicular dominance prior to treatment. Silcox et al., (1993) demonstrated that the ability of dominant follicles to respond to exogenous $\mathrm{GnRH}$ is dependent on the stage of development at the time of treatment. The phases of dominant follicle 
were determined by daily ultrasonography. Similarly, stage of estrous cycle at which synchronization treatment is initiated influences reproductive response of FTAI (Ovsynch protocol) as it affects follicular development and plasma progesterone profiles (Moreira et al., 2001).

In contrast to the other techniques, transrectal real time ultrasonographic screening of animal 's reproductive tract reveals true images of structures which are not possible, otherwise even by highly skilled palpators per rectally (Reeves et al., 1984). Pieterse et al., (1990) compared ultrasonography with rectal palpation and found that for detecting follicles, ultrasonography was a significantly better method than rectal palpation. Application of transrectal real time ultrasonography as a research tool to study bovine reproduction represents a technological breakthrough that has revolutionized our understanding of the reproductive biology. Ultrasonography has been found very useful in identifying CL in the ovary. Ribadu et al., (1994) reported an accuracy of $95.7 \%$ with ultrasonography whereas it was about $85 \%$ with rectal palpation in detecting a CL. Ultrasonography, coupled with hormone estimation, gives the most reliable evaluation of ovarian activity (Ribadu et al., 1994).

\section{Anestrous and its treatment}

Anestrus is classified as either preservice or post-service (Zemjanis, 1980). Preservice anestrus is defined as the absence of observed estrus in the immediate postpartum period. Post-service anestrus is defined as absence of observed estrus following an unsuccessful insemination. The possible underlying reasons for anestrus could be physio-pathological in origin or they may be due to suckling, nutrition, infections of reproductive tract etc.
Various hormonal preparations used for induction of estrus in anestrus buffaloes range from the use of synthetic strogen (stilbestrol), estradiol as valerate or benzoate, gonadotrophins or analogues (Singh and Singh, 1986; Aminudeen, 1991). A variety of progestational compounds have been administered in different forms (Shankar et al., 1996; Kundu, 1998; Malik, 2005) to mimic the luteal function by blocking the release of gonadotrophins from pituitary, so that subsequent withdrawal of these compounds may result in release of gonadotrophins to initiate follicular activity in ovaries with establishment of estrous cycles

\section{Progestogens}

Progestogens have been widely used for induction of estrus and ovulation in acyclic animals. Various progesterone compounds have been administered to mimic the luteal function by blocking the release of gonadotrophins from pituitary, so that the subsequent withdrawal of these compounds may result in release of gonadotrophins to initiate follicular activity in ovaries with establishment of estrous cycles (Peters, 1986). Various progesterone preparations including melengesterol acetate (MGA; Kumar, 1999), progesterone releasing intravaginal device (PRID; Shah et al., 1987), Crestar (Lohan et al., 2001; Malik et al., 2003), Syncromate-B (Zahid et al., 2003; Misra et al., 2003); progesterone and PMSG alone or in combination (Randhawa et al., 2003) have been employed in the treatment of postpartum anestrus buffaloes but with wide variation in induction of cyclicity and subsequent conception rates.

\section{Ear implants}

Auricular implants of progestogen $\left(\right.$ Crestar $^{\circledR}$ or Syncromate-B) have been used to synchronize estrus and ovulation. These implants contain 
norgestomet (17 $\alpha$ - acetoxy-11 $\square$-methyl-19norpreg-4-en-3,20dione) which is more potent than natural progesterone and therefore, lower doses are required. Therefore, hydron implant Syncromate-B presents $6 \mathrm{mg}$ of norgestomet, while silicone implant Crestar ${ }^{\circledR}$ presents $3 \mathrm{mg}$ of norgestomet. Silicone implant causes progesterone like compounds to be released in a more homogenous and linear way, while hydron implant releases norgestomet in high quantities in the first two days and the quantity decreases during the following days (Kesler et al., 1997). Crestar ${ }^{\mathbb{B}}+\mathrm{eCG}$ protocolhas been tried for induction of cyclicity in postpartum buffaloes and heifers by various researchers with varying success (Younis et al., 1996; Lohan et al., 2001; Pant et al., 2002; Dahiya et al., 2003; Pateletal, 2003 and Singh et al., 2004; Malik, 2005).

Upon removal of the implant after 9-10 days, most buffaloes $(>50 \%)$, return to estrus within 3-5 days with first service conception rates ranging from $40-60 \%$ (Singh et al., 1988). If prostaglandin is administered at implant removal, it causes regression of CL and better synchrony (Pargaonkar et al., 1988). In buffaloes a $40 \%$ conception rate has been recorded following FTAI after Syncromate -B treatment (Singh et al., 1983). With this treatment, cycling females may have higher pregnancy rates than acyclic animals (Sanchez et al., 1995), since CL effectively modulates gonadotrophin secretion.

Zicarelli et al., (1997) studied the use of Crestar $^{\circledR}$ and PRID in milking buffaloes under field conditions and demonstrated low efficiency of treatments with pregnancy rates varying from 14.4 to $29.2 \%$ for both groups, respectively. Administration of 500-1000 IU of PMSG at the time of implant removal improves the chances of conception in buffaloes (Singh et al., 1988; Younis et al., 1996; Malik, 2005).

\section{Melengesterol acetate (MGA)}

Feeding MGA @ 0.5-1.0 mg/animal/day for 14-17 days has also been used as a source of progesterone to induce estrus in buffaloes (Shukla et al., 1972). Although cost of treatment is low and means of administration is easy but lower fertility was observed, which may be due to increased number of atretic follicles, failure of follicles to ovulate, reduced size of CL, reduced sperm transport and cleavage rate (Odde, 1990). However, some trials reported better results whenprostaglandinwasadministered 16-18 days after MGA (Rajesh,1999).

\section{Progesterone releasing intravaginal devices}

Progesterone is administered via the intravaginal route by means of intravaginal devices. Initially, sponges were used which posed problem of retention. This led to development of silastic coils (Roche, 1976) and silicon rubber implants (Ellicot et al., 1977) impregnated with progesterone and finally to PRID and CIDR (Welch, 1985). These have not only better retention property but also release progesterone at a controlled rate. MacMillan et al., (1985) found that CIDR-B had better retention property than any other intravaginal device and since then it is the most commonly used intravaginal device. These are used alone or in combination with other hormonal drugs. Incorporation of estradiol benzoate (EB) as a luteolytic agent has enabled short-term PRID/CIDR treatments to synchronize estrus effectively (Singh et al., 1988; Subramaniam and Devrajan, 1991). Using PRID alone for synchronizing estrus in buffaloes gave poor results (Saini et al., 1986), attributed to relatively high incidence of anovulatory estrus. Subramaniam and Devrajan (1991) observed better estrus and conception rates when prostaglandin was administered on the day of CIDR removal than those treated with 
CIDR alone. Bartolomeu et al., (2001) studied the effect of fixed-time artificial insemination in Murrah buffaloes after synchronizing them with CIDR/EB or CIDR/GnRH and got the conception rate of 22.8percent and26.7percent respectively. Murugavel et al (2009) recorded ovulation rate $(81 \%, 47.4 \%)$ and pregnancy rates $(38.1 \%, 21.1 \%)$ in eCG+CIDR and CIDR treated non -cyclic buffaloes, respectively.

\section{GnRH and $\mathrm{PGF}_{2 \alpha}$ combinations}

GnRH has been used to induce LH release and ovulatory cycle in postpartum anestrus buffaloes (Nasr et al., 1983). The GnRH$\mathrm{PGF}_{2 \alpha}$ protocol involves treating animals with $\mathrm{GnRH}$ (day 0) followed by an injection of $\mathrm{PGF}_{2 \alpha}$ on day six for luteolysis. This technique eliminates the need for estrus detection for the six- or seven-days period preceding the $\mathrm{PGF}_{2}$ treatment and enables the synchronized estrus in approximately 80 $\%$ females, during a period of less than four days following $\mathrm{PGF}_{2} \alpha$ induced luteolysis (Twargiramungu et al., 1994). Fertility rates in $\mathrm{GnRH}_{-} \mathrm{PGF}_{2 \alpha}$ treated cows inseminated at detected estrus varied between 65 and $85 \%$ and were identical to those of cows treated with PGF $2 \square$ only (Twargiramungu et al., 1992). Neglia et al., (2003) observed a pregnancy rate of $45 \%$ in buffalo cows synchronized with $\mathrm{PGF}_{2 \alpha}$ alone and $48.8 \%$ when $\mathrm{PGF}_{2 \alpha}$ was combined with $\mathrm{GnRH}$ injection at $\mathrm{AI}$.

\section{GnRH-PGF $2 \alpha^{-}$-GnRH (“Ovsynch")}

A novel protocol for ovulation synchronization named "Ovsynch" was developed for cattle, which makes use of GnRH-PG-GnRH injections (Pursley et al., 1995). This protocol controls follicular development and life span of the CL. The precision of estrus and high fertility rates are due to the GnRH luteinizing orovulating the mature follicle and initiating recruitment and selection of a new dominant follicle. An advantage of this regimen is that it can be use data any stage of the estrous cycle and eliminates the use of progestogen besides promoting the resumption of ovarian activity in acyclic postpartum animals. The use of ovulation synchronization with FTAI in buffaloes provides advantages, similar to those found in cattle and additionally by foregoing the need for estrus detection, which is rather difficult laborious and time consuming (Baruselli et al., 1994).

Follicular wave emergence and luteal regression, with GnRH and PGF $2 \square$ administered 7 days apart, has been practiced with widespread acceptance in dairy herd reproductive management. A second dose of $\mathrm{GnRH}$ given $48 \mathrm{~h}$ after $\mathrm{PGF}_{2 \alpha}$ in Ovsynch program, induces ovulation of the dominant follicle and allows FTAI $16 \mathrm{~h}$ after GnRH (Pursley et al., 1995). When AI was done at fixed time after GnRH- $\mathrm{PGF}_{2 \alpha}-\mathrm{GnRH}$ programme, the pregnancy rates of about 60 $\%$ were obtained in beef cattle (Roy and Twargirumungu, 1996). In dairy cows, pregnancyratesof 40 to55\% were obtained after a FTAI following Ovsynch treatment (Pursley, 1997). Ovsynch protocol was capable of inducing a fertile ovulation in cyclic and anestrus beef cows and the pregnancy rates with FTAI were higher (59\%) than those obtained with synchronized estrus (38\%) using Syncromate-B (Geary et al.,1998).

Mialot et al., (1999) treated anestrus cows (between 60 -90 days postpartum) with GnRH-PGF $2 \alpha^{-} \mathrm{GnRH}$ protocol with FTAI at day $10(n=101)$ or insemination at observed estrus after $2^{\text {nd }} \mathrm{GnRH}$ injection $(\mathrm{n}=93)$. Out of 101 treated, 87 cows were inseminated at FTAI and 35 out of $87(40.2 \%)$ cows conceived whereas $78(64.2 \%)$ cows of 93 were inseminated at observed estrus and 50 
out of 78 cows got finally conceived. In bovines, $100 \%$ cows and $75 \%$ heifers ovulated between 24 and $32 \mathrm{~h}$ after second GnRH injection (Pursley et al., 1995). Fricke et al., (1998). Postpartum interval to beginning of treatment, for synchronization of ovulation with FTAI, may also be important to obtain good conception rates. Pursley et al., (1995) found higher conception rates at 60 days postpartum in animals treated with Ovsynch than control group.

As compared to cattle, very few reportsare available in buffalo on synchronization of ovulation for FTAI (Baruselli et al., 2003). Realizing the importance of such technique in buffaloes due to high incidence of silent estrus (Seren et al., 1995), highly variable duration of estrus and consequent difficulty in predicting time of ovulation (Baruselli, 2001), recently some studies have been published on the use of Ovsynch technique in buffaloes (Berber et al., 2002; Baruselli et al., 2003; Neglia et al., 2003; Paul and Prakash, 2005). Berber et al., (2002) used two Ovsynch protocols with either GnRH or porcine LH on day 9 in post partum buffaloes at organized farm and observed similar ovulation rates $(86.6 \%$ and $93.3 \%)$ after the two GnRH injections, irrespective of LH substitution. Baruselli et al., (2003) treated 33 female buffaloes, 60 days postpartum, with different $1^{\text {st }} \mathrm{GnRH}$ dose of 10 or $20 \mu \mathrm{g}$ and reported $60.6 \%$ ovulations after first GnRH (GroupI= 70.5 vs Group II $=50 \%$ ) and $78.8 \%$ buffaloes had synchronized ovulations after second GnRH injection. Animals synchronized during favourable reproductive season had better conception rates than unfavorable season $(48.8 \%$ vs $6.9 \%)$.

Khanna (2003) conducted a study on 45 postpartum buffaloes (35-45 days postpartum) and used conventional Ovsynch protocol (Day $0-1^{\text {st }} \mathrm{GnRH}(100 \mu \mathrm{g})$, Day 7 $\mathrm{PGF}_{2 \square}(25 \mathrm{mg})$ and Day $9-2^{\text {nd }} \mathrm{GnRH}(100 \mu \mathrm{g})$ in two groups of animals. In Group 1, FTAI was done after 12 and $24 \mathrm{~h}$ of $2^{\text {nd }} \mathrm{GnRH}$ whereas in Group 2, A.I. was done at detected estrus. The overall pregnancy rates were higher in Group2 (60\%) than Group 1 (40.1\%). Number of services per conception were higher $(\mathrm{P}<0.05)$ in Group $1(1.75 \pm 0.17)$ than Group 2(1.33 \pm 0.25$)$

Neglia et al., (2003) compared two estrus synchronization protocols in Italian Mediterranean buffaloes, Group A $(n=111)$ received $100 \mu \mathrm{g}$ GnRH on Day 0, $375 \mu \mathrm{g}$ $\mathrm{PGF}_{2 \alpha}$ on day 7 and $100 \mathrm{~g} \mathrm{GnRH}$ on day 9 (Ovsynch); Group B $(n=117)$ received an intravaginal drug release device (PRID) containing $1.55 \mathrm{~g}$ progesterone and a capsule with $10 \mathrm{mg}$ estradiol benzoate for 10 days plus a luteolytic dose of $\mathrm{PGF}_{2 \alpha}$ and $1000 \mathrm{IU}$ PMSG at PRID withdrawal. They found no difference in overall pregnancy rates between the two protocols (Group A, 36\%; Group B, $28.2 \%$ ).

PaulandPrakash (2005) evaluated efficacy of Ovsynch protocol for synchronization of ovulation and FTAI in Murrah buffaloes. They conducted two experiments, in experiment 1,10 non-lactating cycling buffaloes received $10 \mathrm{~g} \mathrm{GnRH}$ analogue (Buserelin acetate) without regard to stage of the estrous cycle (day of treatment, day=0), followed by $25 \mathrm{mg}$ PGF $2 \alpha 7$ days after first GnRH. A second GnRH injection $(10 \mu \mathrm{g}))$ was given $48 \mathrm{~h}$ after $\mathrm{PGF}_{2 \alpha}$. In experiment 2 , 15 lactating, cycling buffaloes were subjected to the same Ovsynchprotocol with FTAI 12 and $24 \mathrm{~h}$ after $2^{\text {nd }} \mathrm{GnRH}$ treatment. As controls, 75 lactating buffaloes were inseminated $12 \mathrm{~h}$ after detection of spontaneous estrus. In experiment 1 , it was observed that ovulation occurred in $9 / 10$ (90\%) after $2^{\text {nd }} \mathrm{GnRH}$ treatment. In experiment 2, it was observed that pregnancy rates were $33 \%$ for FTAI and $30.7 \%$ for buffaloes inseminated following spontaneous 
estrus, concluding that Ovsynch protocol can effectively synchronize ovulations in Murrah buffaloes. Ali and Fahmy (2007) recorded $62.5 \%$ and $100 \%$ ovulation following first and second GnRH treatments respectively with $37.5 \%$ conception in non -cyclic buffaloes.

\section{Use of eCG-GnRH- PGF $_{2 \alpha}-$ GnRH (Ovsynch-Plus)}

Recently a modified protocol (Ovsynch-Plus) has been tried for induction of synchronized estrus and FTAI in Murrah buffalo heifers (Sharma et al., 2004 andSingh et al., 2004). Sharma et al., (2004) compared the standard Ovsynch protocol and modified protocol (Ovsynch-Plus) in Murrah heifers, Group A $(n=12)$ received standard Ovsynch treatment consisting of $10 \mu \mathrm{g} \mathrm{GnRH}$ on day 0 (start of treatment), $25 \mathrm{mg} \mathrm{PGF}_{2 \alpha}$ on day 7 and second injection of $10 \mu \mathrm{g}$ GnRH on day 9 whereas Group B (Ovsynch-Plus) heifers $(n=9)$ received similar Ovsynch treatment as in group A except that it was preceded by an additional injection of $600 \mathrm{IU}$ eCG, two days prior to start of the Ovsynch treatment.

They observed overall pregnancy rate of 16.7 $\%(2 / 12)$ in Group A, which was considerably improved to $66.7 \%(6 / 9)$ in Group B. Similarly, Singh et al., (2004) also studied the effect of modified protocol of Ovsynch-Plus in buffalo heifers and observed that in Group A $(n=7)$ in which standard Ovsynch protocol was followed, none of the heifers responded to $2{ }^{n d} \mathrm{GnRH}$ whereas in Group B $(n=14)$ in which Ovsynch-Plus protocol was followed, 7/14 (50\%) heifers became pregnant after FTAI. It was clearly indicated that Ovsynch Plusprotocol is comparatively better than Ovsynch alone and it is effective for inducing synchronized behavioral estrus in anestrus heifers with good fertility to fixed time artificial insemination. Ravikumar et al., (2009) observed ovulation and first service conception rate as $100 \%$ vs $83.33 \%$ and
$41.66 \%$ vs $33.33 \%$, respectively in Ovsynch+CIDR vs Ovsynch treatment groups, respectively.

\section{Other non-hormonal treatments}

Biostimulation describes the stimulatory effect of a male on estrus and ovulation through genital stimulation and priming pheromones (Chenoweth, 1983). It was suggested that the presence of male can hasten the onset of puberty (Izard, 1983), which is well documented in sheep and goats (Shelton, 1960). This male effect appears to be olfactory, involving the vomero-nasal organ having neural connections with the hypothalamus and this mediates the effects of priming hormones on ovarian function (Izard, 1983). Exposure of postpartum cows to bulls may shorten the duration of postpartum anestrus and/or increase ovulation (Fernandez et al., 1993) but results are inconsistent. Exposure of postpartum cows to a vasectomized bull for 3-4 h twice daily resulted into cows conceiving from fertile mattings earlier than control cows that were not exposed to teaser (Izard, 1983).

Economic benefits of using biostimulation to enhance induction and synchronization of estrus, reduction of postpartum anestrus, reduction in silent heat and improving ovulation rate may serve as an effective management tool (Singh, 2003). Postpartum anestrus is coupled to early lactating period, when most females, particularly buffaloes, are suckling. Herbal preparations like Janova, Quick Heat, Prajnaetc. have been used in field practice with varying degree of success.

\section{References}

Acharya, R.M. and Bhat, P.N. (1988). Status paper on buffalo production and health. Proceeding of $I^{\text {nd }}$ World Buffalo Congress held in India during 12-16 
Dec., 1: 75-101.

Adams, G.P., Matteri, R.L. and Ginther, O.J. (1992). Effect of progesterone on ovarian follicles, emergence of follicular waves and circulating folliclestimulating hormone in heifers. $J$. Reprod. Fertil. (95): 627-640.

Ali, A. and Fahmy, S. 2007. Ovarian dynamics and milk progesterone concentrations in cycling and noncycling buffalo cows (Bubalus bubalis) during Ovsynch program. Theriogenelogy. 68: 23-28.

Aminudeen (1991). Effect of gonadotrophin releasing hormone on postpartum reproductive efficiency of cross-bred cows: Clinical and endocrine aspects. Ph. D. Thesis submitted to Haryana Agril. University, Hisar (India).

Annual Report (2007-08): Department of Animal Husbandry, Dairying \& Fisheries, Ministry of Agriculture, Government of India, New Delhi.

Anon (2007). Indian Milk- Output to cross 100 million Tonnes Milestone. Indian Food Industry, 26(1): 20.

Bandyopadhyay; A.K., Ray, P.R. and Ghatak, P.K. (2003). Effective utilization of buffalo milk formanufacturingdairyproducts. $4^{\text {th }} \mathrm{Asi}$ anBuffaloCongressleadpapers, 191.

Barile, V.L. (2005). Improving reproductive efficiency in female buffaloes. Livestock Prod. Sci. (92): 183-194.

Barile, V.L. (2005). Improving reproductive efficiency in female buffaloes. Livestock Prod. Sci. (92): 183-194.

Barile, V.L., Galasso, A., Marchiori, E. and Borghese, A. (1997). Effect of PRID treatment on estrus synchronization and progesterone levels in Italian Buffaloes. In: Proceedings of the $5^{\text {th }}$ World Buffalo Congress, Caserta, Italy, pp. 738-743.

Bartolomeu, C.C., Del Rei, A.J.M., Madureira, E.H., Souza, A.J., Silva, A.O. and Baruselli. P.S. (2001). Timed insemination using synchronization of ovulation in buffaloes using CIDR-B, Crestar and Ovsynch. RevistaBrasileira-de-Reproducao-Animal (25): 334-336.

Bartolomeu, C.C., Rei, A.J. del., Baruselli, P.S., Barnbe, R.C., del, A.J. and Vale, W.G. (ed). (2002).

Baruselli, P.S. (2001). Control of follicular development applied to reproduction biotechnologies in buffalo. In: Proceedings of the Congresso Nazionale sull Allevamento del Bufalo Eboli, Italy. pp. 128-146.

Baruselli, P.S., Barnabe, V.H., Barnabe, R.C., Visintin, J.A., Molero-Filho, J.R. Artificial Insemination in buffalo (1994). In: World Buffalo Congress, Sao Paulo, Brazil, Vol. (3): pp. 649651.

Baruselli, P.S., Madurlira, E.Hl., Banarbe, V.H., Barnabe, R.C. and Berber, R.C. de. (2003). Evaluation of synchronization of ovulation for fixed timed insemination in buffalo (Bubalus bubalis). Braz. J. Vet. Res. Anim. Sci. 40: 431-442.

Baruselli, P.S., Mucciolo, R.G., Visintin, J.A., Viana, W.G., Arruda, R.P., Maduriera, E.H., Oliveira,

Berber, RC-de-A., Madureira, E.H. and Barsuelli, P.S. (2002). Comparison oft wo_Ovsynch 'protocols (GnRH versus $\mathrm{LH})$ for fixed time insemination in buffalo (Bubalus bubalis). Theriogenology (57): 1421-1430.

Borghese, A., Barile, V., Terzano, G., Annicchiarico, G., Debenedetti, A. and Malfatti, A. (1993). In: Anoestrus length in Italian buffalo cows. Note I. 389-392.

Borghese, A., Terzano, G.M., Barile, V.L., Annicchiarico, G., Allegrini. S., Esposito, L., Di Palo, R., Boni, R., Seren, E. and Parmeggiani, A. (1994). Pubertae mantenimentodell attivitaciclica 
ovaricanella buffalo (Puberty and maintenance of ovarian cyclic activity in buffalo). Agric. Ric. (153): 5-16.

Buckrell, B.C. (1988). Application of ultrasonography in reproduction in sheep and goats. Theriogenology., 29: 71-84.

C.A. and Molero Filho, J.R. (1997). Ovarian follicular dynamics during the oestrous cycle in buffalo. Theriogenology (47): 1531-1547.

Campo, E., Alonso, J.C., Hincapie, J.J., Libertad, G., Faure, O. and Fernandez, O. (2002). Seasonal influence on uterine involution and postpartum ovarian activity in river buffaloes. Bubalus bubalis (3): 59-63.

Chenoweth, P.J. (1983). Reproductive management procedures in control of breeding. Aust. J. Anim. Prod. (15): 2833.

Dahiya, V., Lohan, I.S., Saini, M.S., Kaker, M.L. and Malik, R.K. (2003). Ultrasonographic assessment of ovarian changes in anoestrus buffaloes treated with norgestomet. Indian J. Anim. Sci. (73): 1033-1036.

Dairy India. (2007). $6^{\text {th }}$ edition published by Dairy India Year Book, New Delhi.

De Rensis, F., Ronci, G., Guarneri, P., Nguyen, B.X., Presicce, G.A., Huszenicza, G. and Scaramuzzi, R.J. (2005). Conception rate after fixed time insemination following Ovsynch protocol with and without progesterone supplementation in cyclic and non-cyclic Mediterranean Italian buffaloes (Bubalus bubalis). Theriogenology (63): 1824-1831.

Ellicot, A.R., Thompson, C.E. and Hill, J.R.Jr. (1977). Pregnancy rates in cows and heifers inseminated at predetermined times using progesteronereleasing intravaginal devices. Theriogenology, 8: 315-321.

El-Wishy, A.B. (2007). The postpartum buffalo. II Acyclicity and anestrus.
Anim. Reprod. Sci., 97: 216-236.

Esposito, L., Campanile, G., Di Palo, R., Boni, R., Di Meo, C. and Zicarelli, L. (1992). Seasonal reproductive failure in buffaloes bred in Italy. In: Proc. of the $12^{\text {th }}$ International Congr. Anim. Reprod. The Hague, The Netherlands: pp. 20462047.

Fernandez, D., Berardinelli, J.G., Short, R.E. and Adair, R. (1993). The time required for the presence of bulls to alter the interval from parturition to resumption of ovarian activity and reproductive performance in first calf suckled beef cows. Theriogenology (39): 411-419.

Fricke, P.M., Guenther, J.N. and Wiltbank, M.C. (1998). Efficacy of decreasing the dose of GnRH used in protocol for synchronization of ovulation and timed AI in lactating dairy cows. Theriogenology (50):1275-1284.

Garcia, A., Weijden, A., Colenbrander, B. and Bevers, M.M. (1999). Monitoring follicular development in cattle by realtime ultrasonography: A review. Vet. Rec., 145:334-340.

Geary, T.W., Whittier, J.C., Doconing, E.R., Le Fever, D.G., Silcox, R.W., Holland, M.D., Nett, T.M. and Niswander, G.D. (1998). Pregnancy rates of postpartum beef cows that were synchronized during Synchromate-B or the Ovsynch protocol. J. Anim. Sci. (76): 1523-1527.

Griffin, P.G and Ginther, O.J. (1992). Research applications of ultrasonic imaging in reproductive biology. $J$. Anim. Sci., 70: 953-972.

Izard, M.K. (1983). Pheromones and reproduction in domestic animals. In: Vandenbergh, J.G. (ed.). Pheromones and Reproduction in Mammals. Academic Press, New York, pp. 253285.

Jainudeen, M.R. (1984). Reproduction in the water buffalo: postpartum female. Proc. $10^{\text {th }}$ Int. Congr. Anim. Reprod. And AI. 
Urbana, Vol. (4): pp. 42-49.

Jainudeen, M.R. and Hafez, E.S.E. (1993). Cattle and buffalo. In: Hafez, E.S.E. (Ed.), Reproduction in Farm Animals, $6^{\text {th }}$ ed. Lea and Febiger, Philadelphia, pp. 315-329.

Jainudeen, M.R., Wahid, H and Hafez, E.S. E (2000). Sheep and goats. In: Reproduction in farm animals. B. Hafez and E.S.E. Hafez, (Eds.). Williams and Wilkins, Philadelphia, USA, pp. 172181.

Jainudeen, M.R., Sharifuddin, W. and Bashir Ahmed, F. (1983). Relationship of ovarian contents to plasma progesterone concentration in the swamp buffalo (Bubalus bubalis). Vet. Rec. (113): 369372.

Janakiraman, K. (1978). Control and optimizing of reproductive cycle in buffalo. Proc. FAO/SIDA/Govt. of India. Seminar on Buffalo Reproduction and Artificial Insemination, NDRI, Karnal (India) pp. 220-225. Gill, R.S., Gangwar, P.C. and Komer, D.S. (1973). Studies on the oestrousbehaviour in buffaloes. Indian J. Anim. Sci. (43): 472-475.

Johnson, B.M., Nuti, L.C. and Wiltz, D. (1994). Ultrasonographic examination of the caprine ovary. In Practice, 89: 477-480.

Kaker, M.L., Galhotra, M.M and Razdan, M.N (1981). Serum prolactin levels of cycling Murrah buffaloes during summer and winter. Indian J. Dairy Sci.., 34: 391-395.

Kesler, D.J., Faulkner, D.B. and Mash, T.G. (1997). Norgestomet implantation in beef females. Large Anim. Pract. (18):26-30.

Khanna, S. (2003). Induction of oestrus in postpartum buffaloes with $\mathrm{GnRH}-$ $\mathrm{PGF}_{2 \square}-\mathrm{GnRH}$ regimen: Ultrasonographic and endocrinological studies. Ph.D. Thesis, CCS Haryana
Agricultural University, Hisar(India).

Kumar, R. (1999). Fertility responses of anestrus postpartum buffaloes to progestogen therapy during low breeding season. M.V.Sc. thesis, CCS Haryana Agricultural University, Hisar (India).

Kumar, R., Saxena, A. and Niranjan, P. S (2009). Estrus detection by serum progesterone concentration in buffaloes. Indian Vet. J., 86: 326-327.

Kumar, S. and Sharma, S.C. (1991). Hematological changes during fertile and non-fertile estrus in rural buffaloes. Buffalo J., 9(1): 69-73.

Kundu, A.S. (1998). Management of summer anestrus in postpartum buffaloes with norgestomentestrodiol-eCG combination-Clinical and endocrinestudies. MVSc. Thesis submitted to CCS Haryana Agricultural University, Hisar (India).

Lakra, B.S. (2002). Studies on the reproductive performance of non-cyclic Murrah buffaloes with assisted reproductive technique. M.V.Sc. Thesis, CCS HAU, Hisar, India.

Lohan, I.S., Saini, M.S., Kaker, M.L., Malik, R.K., Singh, B. and Grewal, S.S. (2001). Follicular changes in postpartum buffaloes (Bubalus bubalis) induced to cyclicity. Indian J. Anim. Sci. (71):918-921.

Lohan, I.S., Saini, M.S., Kaker, M.L., Malik, R.K., Singh, B. and Grewal, S.S. (2001). Follicular changes in postpartum buffaloes (Bubalus bubalis) induced to cyclicity. Indian J. Anim. Sci. (71):918-921.

Luktuke, S.N. and Ahuja, L.D. (1961). Studies on ovulation in buffaloes. $J$. Reprod. Fertil. (2): 200- 201.

Lundstorm, K., Abeygunawardena, H., de Silva, L.N.A. and Perera, B.M.A.O. (1982). Environmental influence on calving interval and its repeatability in 
Murrah buffaloes in Sri Lanka. Anim. Reprod. Sci. (5): 99-109.

Macmillan, K.L., Taufa, V.F. and Barnes, D.R. (1985). Development of CIDR dispensers for oestrus control in dairy cattle. NewZealand Ministry of Agric and Fisheries. Agric. Research division Annual Report, 86: 30.

Malik, R.K. (2005). Studies on ovarian follicular dynamics during early postpartum period, anestrus condition and hormonal therapies for induction of estrus in Murrah buffaloes (Bubalus bubalis). Ph.D. Thesis submitted to CCS Haryana Agricultural University, Hisar (India).

Malik, R.K. (2005). Studies on ovarian follicular dynamics during early postpartum period, anestrus condition and hormonal therapies for induction of estrus in Murrah buffaloes (Bubalus bubalis). Ph.D. Thesis submitted to CCS Haryana Agricultural University, Hisar (India)

Malik, V.S., Kaker, M.L. and Lohan, I.S. (2003). Diameter of largest, second largest follicles and level of estrodiol$17 \beta$ during different physiological phases in postpartum anoestrus buffaloes induced to cyclicity during winter and summer seasons. In: Proc. $4^{\text {th }}$ World Buffalo Congress, New Delhi, pp. 122.

Malik, V.S., Kaker, M.L. and Lohan, I.S. (2003). Diameter of largest, second largest follicles and level of estrodiol$17 \beta$ during different physiological phases in postpartum anoestrus buffaloes induced to cyclicity during winter and summer seasons. In: Proc. $4^{\text {th }}$ World Buffalo Congress, New Delhi, pp. 122.

Manik, R.S., Ambrose, J.D., Singla, S.K., Chauhan, M.S. and Madan, M.L. (1994). Real time ultrasound evaluation of follicular changes in super ovulated
Murrah buffaloes. Buffalo J. (10): 139146.

Markandeya, N.M., Pargaonkar, D.R. and Bakshi, S.A. (1993). Studies on vaginal electrical resistance associated with estrus in buffaloes. Buffalo J. (9): 157158.

Mialot, J.P., Laumonnier, G., Pansert, C., Fauxpoint, H., Barassin, E., Ponter, A.A. and Deltang, F. (1999). Postpartum suboestrus in dairy cows: Comparison of treatment with PGF2 $\square$ or $\quad$ GnRH- $\quad$ PGF2 $\square+\mathrm{GnRH}$. Theriogenology (52): 901-911.

Misra, A.K., Kasiraj, R., Mutha Rao, M., Ranga Reddy, M.S. and Pant, H.C. (2003). Synchro-mate B induced estrus in functionally anoestrus buffaloes (Bubalus bubalis). Ind. J. Anim. Sci. (73): 239-244.

Misra, A.K., Kasiraj, R., Mutha Rao, M., Ranga Reddy, M.S. and Pant, H.C. (2003). Synchro-mate B induced estrus in functionally anoestrus buffaloes (Bubalus bubalis). Ind. J. Anim. Sci. (73): 239-244.

Misra, A.K., Kasiraj, R., Mutha Rao, M., Ranga Reddy, M.S. and Pant, H.C. (2003). Synchro-mate B induced estrus in functionally anoestrus buffaloes (Bubalus bubalis). Ind. J. Anim. Sci. (73): 239-244.

Moreira, F., Orlandi, C., Risco, C.A., Mattos, R., Lopes, F. and Thatcher, W.W. (2001). Effects of pre- synchronization and bovine somatotropin on pregnancy rates to a timed artificial insemination protocol in lactating dairy cows. $J$. Dairy Sci. (84): 1646-1659.

Munugavel, K. Antoine, D. Raju, M.S. and Lopez, Gatius, F. 2009. The effect of addition of equine chornic gonedotropin to a progesterone based estrous synchronization protocol in buffaloes (Bubalus bubalis) under tropical conditions. Theriogenology. 71: 1120- 
1126.

Nagaraju, N., Reddy, V.S.C., Rao,A.S., Sharma, G.P., Reddy, G.V.N. and Reddy, C.E. (1991). Studies on certain biochemical constituents of blood in cycling and true anestrus buffaloes during post-partum period. Cherion, 20: 6-8.

Nasr, M.T., Sharwy, S.M., El-Azab, M.A. and Labib, F.M. (1983). Induction of estrus and improvement of fertility in anestrus cows and buffaloes with Receptal. Zuchthygiene (18): 129-135.

Neglia, G., Midea, D., Caracciolodi Brieza, V., Rossi, N., Zicarelli, F. (2001). Associazionedel GnRH allaprostaglandinenellainseminazionestru mentaledellabufaloMediterraneaItaliana.

In: Proceedings of the Congress Nazionale sullAllevamentodel Bufalo, Eboli (Italy). pp. 337-340.

Odde, K.G. (1990). A review of synchronization of estrus in postpartum cattle. J. Anim. Sci. (68): 817-830.

Pandit, R. K (2004). Incidence of different kinds of reproductive disorders in livestock. Indian J. Anim. Reprod.,. 25:35-36.

Pant, H.C., Barot, L.R., Dugwekar, Y.G., Kasiraj, R. and Prabhakar, J.H. (2002). Hormonal induction of oestrus in anoestrus buffaloes. Indian J. Anim. Reprod. (23): 32-34.

Pargaonkar, D.R., Bakshi, S.A. and Joshi, S.A. (1988). Induction of estrus in buffaloes. In: Proc. $2^{\text {nd }}$ World Buffalo Cong., New Delhi, India, Dec. 12-16, Vol.(3): 119-120.

Parkinson, T.J. (2001). Infertility in cow. In: Veterinary Reproduction and Obstetrics. Noakes, D.E., Parkinson, J.J. and England, G.C.W., 8th Edn. W.B. Sounders Company Philadelphia, pp. 415-556.

Parmeggiani, A., Seren, E., Esposito, L., Borghese, A., Di Polo, R. and Terzano,
M.G. (1993). Plasma levels of melatonin in buffalo cows. Proc. International symposium "Prospect of Buffalo Production in the Mediternean and in the Middle East, Cairo, Egypt, EAAP Publ. (62): 401- 403.

Patel, D.M., Sarvaiya, N.P., Patel, A.V., Parmer, A.P. and Dugwekar, Y.G. (2003). Induction of estrus and hormonal profile in buffalo treated with norgestomet ear implant. Indian $J$. Anim. Reprod. (24): 67-68.

Paul, V. and Prakash, B.S. (2005). Efficacy of the Ovsynch protocol for synchronization of ovulation and fixed time artificial insemination in Murrah buffaloes (Bubalus bubalis). Theriogenology. In Press.

Peters, A.R. (1986). Hormonal control of the bovine oestrous cycle: Pharmacological principles. Br. Vet. J. (142):20-29.

Pierson, R.A. and Ginther, O.J. (1988). Ultrasonic imaging of the ovaries and uterus in cattle. Theriogenology (29): 21-37.

Pieterse, M.C., Taverna, M.A.M., Kruip, T.A.M. and Willemse, A.H. (1990). Detection of corpora lutea and follicle in cows: A comparison of transvaginal ultrasonography and rectal palpation. Vet. Rec. (126): 552-554.

Proceedings of $1^{\text {st }}$ Buffalo symposium of Americas, Belam, Brazil: 410-413.

Pursley, J.R., Kosorok, M.R. and Wiltbank, M.C. (1997). Reproductive management of lactating dairy cows using synchronization of ovulation. J. Dairy Sci. (80): 301-306.

Pursley, J.R., Kosorok, M.R. and Wiltbank, M.C. (1997). Reproductive management of lactating dairy cows using synchronization of ovulation. J. Dairy Sci. (80): 301-306.

Pursley, J.R., Mee, M.O. and Wiltbank, M.C. (1995). Synchronization of ovulation in dairy cows using $\mathrm{PGF}_{2 \square}$ and GnRH. 
Theriogenology (44): 915-923.

Pursley, J.R., Mee, M.O. and Wiltbank, M.C. (1995). Synchronization of ovulation in dairy cows using $\mathrm{PGF}_{2} \square$ and $\mathrm{GnRH}$. Theriogenology (44): 915-923.

Rajamahendran, R., Ambrose, D.J. and Burton, B. (1994). Clinical and research application of real- time ultrasonography in bovine reproduction: A Review. Can Vet. J. (35): 563-572.

Rajesh (1999). Fertility responses of anestrus postpartum buffaloes to progesterone therapy during low breeding season. MVSc thesis, CCS Haryana Agricultural University, Hisar (India).

Randhawa, B., Pangaonkar, G.R., Brar, P.S., Nanda, A.S. and Gandotra, V.K. (2003). Response to gonadotropin treatment of postpartum anestrus buffaloes after supplementary feeding. In: Proceeding $4^{\text {th }}$ World Buffalo Congress, pp. 117-118.

Ravikumar, K., Asokan, S.A. and Veerapandian, C. 2009. Inclusion of CIDR in Ovsynch protocol to improve fertility in postpartum subestrus buffaloes. Indian Journal of Animal Reproduction, 30(1).

Ravikumar, K., Asokan, S.A. and Veerapandian, C. (2005). Inclusion of CIDR in Ovsynch protocol to improve fertility in postpartum subestrus buffaloes. Indian J. Anim. Reprod. (26): 149-152.

Reeves, J.J., Rantanen, N.W. and Hauser, M. (1984). Transrectal real time ultrasound scanning of cow reproductive tract. Theriogenology (21): 485-494.

Ribadu, A.Y., Ward, W.R. and Dobson, H. (1994). Comparative evaluation of ovarian structures in cattle by palpation per rectum, ultrasonography and plasma progesterone concentration. Vet. Rec. (135): 452-457.

Roche, J.F. (1976). Calving rate of cows following insemination after a 12-day treatment with silastic coils impregnated with progesterone. J.Anim. Sci. (43): 164.6

Rohilla, N. (2003). Effect of pre-treatment ovarian status on response to =Ovsynch 'protocol in summer anestrus postpartum buffaloes. MVSc. Thesis, CCS Haryana Agricultural University, Hisar (India).

Roy, G.L. and Twargiramungu, H. (1996). A fixed time AI programme using the GnRH-PGF $2 \square-G n R H$ method for beef females. J. Anim. Sci. (74): 222 (Abstr.).

Saini, M.S. and Lohan, I.S. (2003). Seasonal effect on induction of estrus and conception rate in postpartum buffaloes treated with GnRH. In: Proc. $4^{\text {th }}$ World Buffalo Cong. pp. 127- 128 .

Sanchez, T., Wehrman, M.E., Bergfeld, E.G., Petters, K.E., Kojima, F.N., Cupp, A.S., Mariscal, V., Kittok, R.J., Rasby, R.J. and Kinder, J.E. (1995). Pregnancy rate is greater when the corpus luteum is present during the period of progestin treatment to synchronize time of estrus in cows and heifers. Biol. Reprod. (49): 1102-1107.

Seren, E., Parmegiani, A. and Campanile, G. (1995). The control of ovulation in Italian buffalo. In: Proceedings of the $X X X \quad$ SiomposioInternazionale $d i$ Zootecnia (Reproduction and Animal Breeding: Advances and Strategy), Milano, pp. 265-275.

Shah, S.N.H., Willemse, A.H. and Van De Wiel, D.F.M. (1987). Induction of ovulatory oestrus in true anoestrus buffaloes during low breeding season. Anim. Reprod. Sci. (14): 233-238.

Shah, S.N.H., Willemse, A.H. and Van De Wiel, D.F.M. (1987). Induction of ovulatory oestrus in true anoestrus buffaloes during low breeding season. Anim. Reprod. Sci. (14): 233-238.

Shankar, V.,Singh, G.D., Upadhaya, M.P. and Pant, H.C.(1996). Treatment of 
true anestrus in bovine with progesterone and estrogen. Indian J. Anim. Reprod. (17):1.

Sharma, R.K., Singh, I., Singh, J.K. and Sethi, R.K. (2004). =Ovsynch-Plus ${ }^{6}$ - A new protocol for synchronized estrus induction and fixed time insemination in peripubertal Murrah buffalo heifers. Proc. National Symposium on livestock biodiversity vis-à-vis resource exploitation. An introspection, Karnal (India) p. 199(Abstr.).

Shelton, M. (1960). The influence of the presence of male goat on the initiation of oestrousand ovulation in Angora does. $J$. Anim. Sci. (19): 368-375.

Short, R.E., Bellows, R.A., Staigmiller, R.B., Berardinelli, J.G. and Custer, E.E. (1990). Physiological mechanisms controlling anestrus and infertilities in post-partum beef cattle. J. Anim. Sci., 68:799-816.

Shukla, K.P., Mithuji, G.F. and Buch, N.C. (1972). Induction of estrus in postpartum Surti buffaloes treated with melengesterol acetate. Ind. J. Anim. Sci. (42): 993-995.

Silcox, R.W., Powell, K.L. and Kiser, T.E. (1993). Ability of dominant follicles to respond to exogenous $\mathrm{GnRH}$ administration is dependent on the stage of development. J. Anim. Sci. (71): 219 (Abstr.).

Singh, A.S., Saxena, M.S. and Shiv Prasad (2004). Efficacy of Crestar ${ }^{\circledR}$ and its combination with Folligon on postpartum anoestrus in buffalo. Indian J. Anim. Reprod. (25): 43-44.

Singh, A.S., Saxena, M.S. and Shiv Prasad (2004). Efficacy of Crestar ${ }^{\circledR}$ and its combination with Folligon on postpartum anoestrus in buffalo. Indian J. Anim. Reprod. (25): 43-44.

Singh, G., Dhaliwal, G.S., Sharma, R.D. and Biswas, R.K. (1988). Treatment of summer anestrus buffalo (Bubalus bubalis) with the progesterone releasing intravaginal device plus pregnant mare serum gonadotrophin. Theriogenology, 29: 1201-1206.

Singh, G., Singh, G.B., Sharma, R.D. and Nanda, A.S. (1983). Experimental treatment of summer anoestrous buffaloes with Norgestomet and PRID. Theriogenology (19): 323-329.

Singh, K. (2003). Use of bio-stimulation in improving reproductive efficiency. Proc. $4^{\text {th }}$ Asian Buffalo Congress on Buffalo for food security and rural employment, New Delhi (India) Vol. (9): pp. 284-289.

Singh, L.P. and Singh, B.K. (1986). Studies on incidence and treatment of anestrus desi cow. Indian Vet. J. (63): 961-962.

Sreemannarayana, O. and Rao, N. (1996). Incidence of fertility disorders in riverine buffaloes in India. Buffalo Bulletin, 15(3): 58.

Subramaniam, A. and Devarajan, K.P. (1991). Estrus synchronization in non-descript Indian Buffaloes with a new intravaginal pessary and $\mathrm{PGF}_{2 \square}$. Buffalo J. (1): 101105.

Taneja, M., Ali, A. and Singh, G. (1996). Ovarian follicular dynamics in water buffalo. Theriogenology (46): 121-130.

Thornton, P.K., Kruska, R.L., Henninglr, N., Kristijanan, P.M., Reid, R.S., Atieno, F., Odero, A.N. and Ndegwa. T. (2002). Mapping poverty and livestock in the developing world. Nairobi: International Livestock Research Institute.

Twagiramungu, H., Guilbault, L.A., Proulx, J.G. and Dufour, J. (1994). Influence of corpus luteum and induced ovulation on ovarian follicular dynamics in postpartum cows treated with buserelin and cloprostenol. J. Anim. Sci. (42): 1796-1805.

Twagiramungu, H., Guilbault, L.A., Proulx, J.G. and Dufour, J.J. (1992). Synchronization of estrus and fertility in 
beef cattle with two injections of buserelin and prostaglandin. Theriogenology (38): 1131-1137.

Welch, R.A.S. (1985). Mating heifers with CIDR. Proceedings of the Ruakura farmers conference, 37: 105.

Younis, M., Soliman, M., Essawy, G.S., Otteifa, A.A., Fadaly, M., Essawy, S.A. and Abass, H.I. (1996). Induction of estrus and pregnancy rate in noncycling Egyptian buffalo heifers. Buffalo. J. (1): 57-63.

Zahid, M.N., Chaudhary, R.A., Rashid, H.B. and Saeed, A.M. (2003). Induction of estrus in non-cyclic postpartum buffaloes through Norgestomet ear implant. In: proceeding $4^{\text {th }}$ World Buffalo Congress, New Delhi, pp. 133134.

Zemjanis, R. (1980). Anoestrus in cattle. In: Morrow, D.A. (ed.). Current Therapy in Theriogenology. W.B. Saunders Co. Philadelphia, 1980, pp. 193-199.

Zicarelli, L. (1997). Reproductive seasonality in buffalo. Third Course on biotechnology of reproduction in buffaloes. Bubalus bubalis. Suppl. (98): 29-52.

\section{How to cite this article:}

Sandeep Kumar, Gaurav Kumar and Subhash Chand Gahalot. 2019. Anestrous in Buffaloes and Different Treatment Regimens: A Mini Review. Int.J.Curr.Microbiol.App.Sci. 8(03): 11621179. doi: https://doi.org/10.20546/ijcmas.2019.803.138 